\title{
Experimental Study of a PEMFC System with Different Dimensions of the Serpentine Type Channels from Bipolar Plate Flow Fields
}

\author{
Adriana ANDRONIE*, Ioan STAMATIN**, Valentin GIRLEANU***, Viorel IONESCU****, \\ Nicolae BUZBUCHI****** \\ *University of Bucharest, Faculty of Physics, 3Nano - SAE Research Center, Bucharest, 077125, Romania, \\ E-mail: adriana.andronie@gmail.com \\ **University of Bucharest, Faculty of Physics, 3Nano - SAE Research Center, Bucharest, 077125, Romania, \\ E-mail: istarom@3nanosae.org \\ ***University of Bucharest, Faculty of Physics, 3Nano - SAE Research Center, Bucharest, 077125, Romania, \\ E-mail: valentin.rata@ymail.com \\ ****Department of Physics and Electronics, Ovidius University, Constanta, 900527, Romania, \\ E-mail: ionescu.vio@gmail.com \\ ****Doctoral School of Mechanical Engineering and Mechatronics, Maritime University, Constanta, 900663, Romania \\ *****Department of Engineering Sciences, Maritime University, Constanta, 900663, Romania, \\ E-mail: nicolae_buzbuchi@yahoo.com
}

crossref http://dx.doi.org/10.5755/j01.mech.25.1.21907

\section{Introduction}

Proton exchange membrane fuel cell (PEMFC) represent at this moment one of the most attractive clean energy source for automotive applications, being, for example, a fundamental component of the Fuel Cell Hybrid Electrical Vehicle(FCHV) with an energy system containing mainly a PEM fuel cell stack and a battery/ultracapacitor storage $[1,2]$. PEMFC present some very interesting characteristics, like low-temperature operation $\left(50-100^{\circ} \mathrm{C}\right)$, high power density $(40 \%-60 \%)$ and nearly zero pollutants compared to conventional internal combustion gasoline vehicles [3, 4], water being the only by-product obtained from the electrochemical reaction at cathode.

The bipolar plates with special flow field patterns represent one important component of a PEM fuel cell. The effect of the various flow channels design on the PEMFC performance was intensively investigated in different numerical and experimental studies. Experimental tests performed in order to compare the PEMFC performance of four types of flow field designs: serpentine, parallel, pin, and interdigitated showed that serpentine configuration for the flow channels conducted to the highest output power of all $[5,6]$.The serpentine flow field can offer an efficient water removal(preventing water flooding) with a moderate pressure drop along the channels, presenting also a good humidity in the cathode channels in order to avert the electrolyte membrane dehydration[7-9].

Many other research studies were oriented on the optimization of cross-section area for flow channels, especially the channel width and the distance between two adjacent channels (channel ribs). The influence of channel to rib width ratio (varied between 0.5 and 2) on the PEMFC electrical performance was experimentally investigated for a serpentine-type flow field and the ratio of unity presented best performances concerning the VI/PI electrical curves [10]. For this study, the active area of the flow field was $5 \mathrm{~cm}^{2}$, with MEA based of Nafion 117 electrolyte membrane and CL having Pt loading of 1 and $0.5 \mathrm{mg} / \mathrm{cm}^{2}$ on anode and cathode, respectively.
A numerical CFD study of a PEMFC system, based on a serpentine flow field with 25 channels and active area of $26 \mathrm{~cm}^{2}$ indicated an optimal channel to rib width ratio of 0.25 [11]. Another numerical study for PEMFC with a serpentine flow field of $25 \mathrm{~cm}^{2}$ active area, performed with CFD Fluent 14.0 software and with Taguchi method integrated in MINITAB 17 software for design optimization relieved and optimum channel to rib width ratio of 1 [12].

Despite the large number of numerical investigations reported already for the flow field design in PEMFC, more experimental studies are needed in order to establish an optimal relation between channel and rib widths, generally accepted for a future development of bipolar plates.

The effects of backpressure on the performance of the PEMFC have been studied recently through experiment and by theoretical modeling. Increasing levels of backpressure resulted in increases in the exchange current densities of the electrochemical reactions, with the increase in the reactant partial pressures and determine an enhancement of the fuel cell performance by increasing the oxygen and hydrogen diffusion to the active sites of the catalyst layer (CL) $[13,14]$. Higher local current densities at CL surface will be generated when pressure inside the PEMFC cell is increased [15].

In this experimental study we investigated the effect produced by three flow fields with serpentine-type channels having different rib to channel width ratios $(1,1.05$ and 1.2) on VI/PI electrical curves and on the thermodynamic efficiency of the PEMFC unit cell. In order to establish an optimal flow field for the fuel cell working in different pressure conditions, the backpressure of the test system was modified at two different values $(70 \mathrm{kPa}$ and $30 \mathrm{kPa})$.

\section{Experimental set-up}

Fuel cell performance at different backpressures was measured using a BEKKTECH BT-552 PEMFC test station (based on a single PEM fuel cell unit) in the laboratory of Fuel Cell and Hydrogen Storage, 3Nano-SAE Research Center, Bucharest. The membrane - electrode assembly (MEA) placed inside the cell was Nafion 212 type and 
catalyst layers (CL) were characterized by Pt loading of $0.3 \mathrm{mg} / \mathrm{cm}^{2}$ at anode and $0.6 \mathrm{mg} / \mathrm{cm}^{2}$ at cathode, with $20 \mathrm{wt} \%$ percent of $\mathrm{Pt} / \mathrm{C}$ catalyst particles.

The experimental set-up presented in Fig. 1 consists of primary components, i.e., Agilent 6060 B 300W electronic load, two MKS RS-485 mass flow controllers, inlet pressure gauges for $\mathrm{H}_{2}, \mathrm{~N}_{2}$ and air, outlet pressure gauges for $\mathrm{H} 2$ and air, two heated/insulated gas lines, $\mathrm{H}_{2} / \mathrm{N}_{2} /$ air tubes with various on/off valves, temperature controllers and two manually controlled back pressure regulators. The components of the PEM fuel cell unit from Fig. 1 are schematically represented in detail in Fig. 2, were: 1 - gas inlet tube, 2 - gas outlet tube, 3 - end plate, 4 - sealing gasket, 5 - current collector, 6 - graphite bipolar plate, 7 - Teflon gasket, 8 - Membrane Electrode Assembly(MEA), 9 - fastening screws.

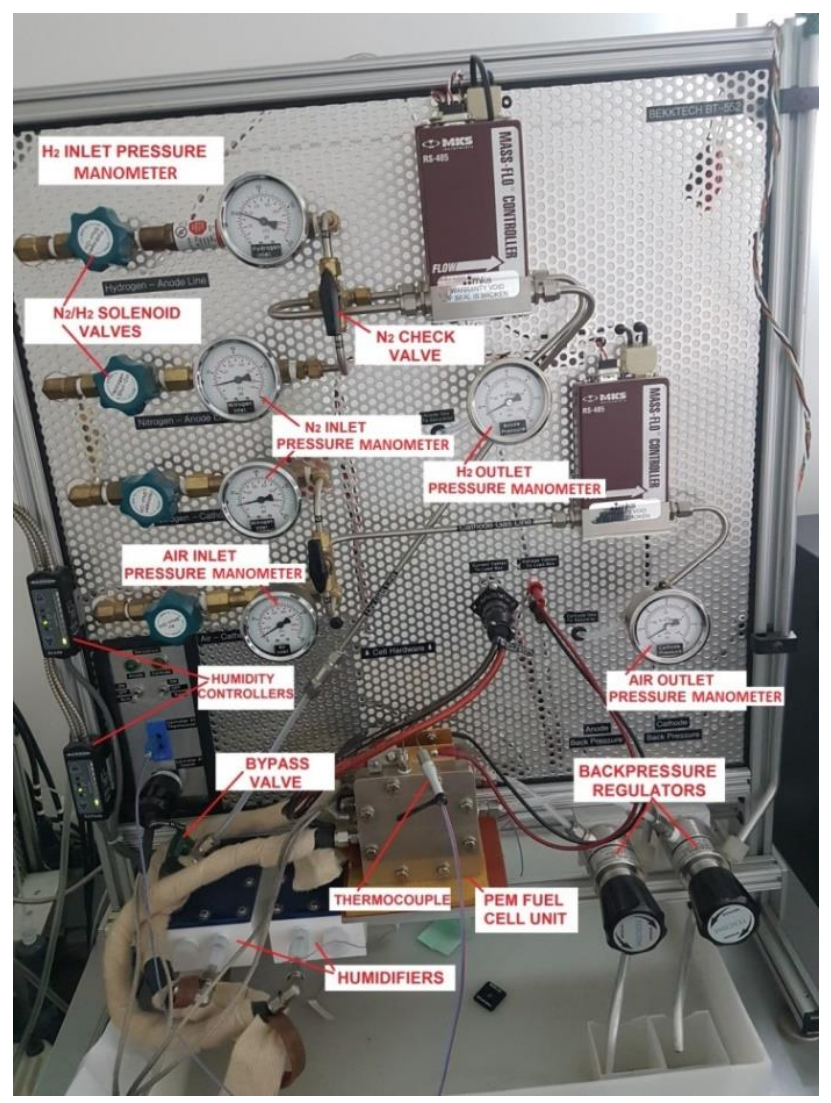

Fig. 1 BEKKTECH BT-552 PEM fuel cell station used in experiments

Reactant gases are humidified by a humidification system which includes dual temperature controller with output gas line heaters and on/off bypass valves. The relative humidity for $\mathrm{H}_{2}$ and air flows circulating through the cell was controlled by adjusting the dew point temperature of the inlet flows.

Operational parameters like temperature, flow rate, relative humidity of the supplied gases, stoichiometry along with current and voltage were recorded and controlled by using a LabVIEW based control and data acquisition system.

The operational parameters for the PEMFC system, chosen according to the automotive applications are shown in Table 1 and are maintained constant during exper- imental tests. Here, $P_{\text {ref,a } a}$ and $P_{r e f, c}$ are the operating pressures of hydrogen and air at the PEMFC system entrance, before humidification stage.

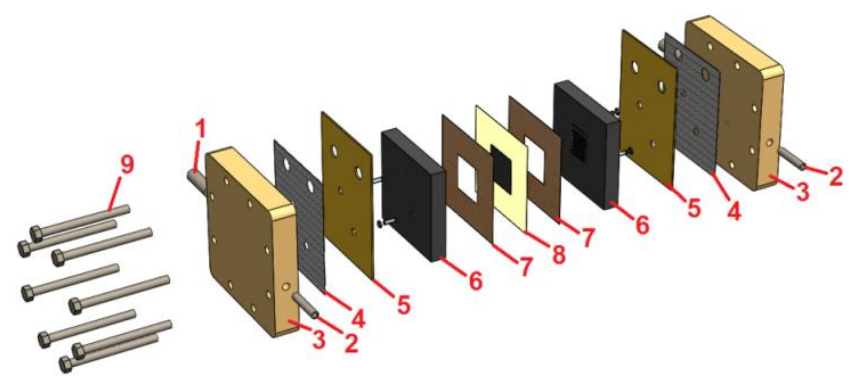

Fig. 2 Schematic representation of the PEM unit cell used in the BEKKTECH BT-552 testing system, with all components included

Table 1

The reference values for the cell temperature, inlet pressure for $\mathrm{H}_{2}$ and air before humidification and the "dew point" temperature (for $80 \% \mathrm{RH}$ ) used in experiments

\begin{tabular}{|c|c|}
\hline Parameter & Value \\
\hline$T_{\text {ref,cell }}\left({ }^{\circ} \mathrm{C}\right)$ & 80 \\
\hline$T_{\text {ref }, a}\left({ }^{\circ} \mathrm{C}\right)$ & 95 \\
\hline$T_{\text {ref,c } c}\left({ }^{\circ} \mathrm{C}\right)$ & 95 \\
\hline$T_{r e f, d p, a}\left({ }^{\circ} \mathrm{C}\right)$ & 74.6 \\
\hline$T_{r e f, d p, c}\left({ }^{\circ} \mathrm{C}\right)$ & 74.6 \\
\hline$P_{r e f, a}(\mathrm{KPa})$ & 300 \\
\hline$P_{r e f, c}(\mathrm{KPa})$ & 200 \\
\hline
\end{tabular}

The pressures at the exit of the fuel cell system (backpressures) for the anode and cathode were:

$P_{1 \text { an }}^{\text {backressure }}=P_{1 \text { cat }}^{\text {backressure }}=70 \mathrm{kPa}$ for Test no. 1

and $P_{2 \text { an }}^{\text {backressure }}=P_{2 \text { cat }}^{\text {backressure }}=30 \mathrm{kPa}$ for Test no. 2 .

The pressure of humidified gases crossing the fuel cell (from entry to exit) will be considered constant during the test period and estimated in the form of an average value, according to the relations [13]:

$$
\begin{aligned}
& \bar{P}_{i a n}=\frac{1}{2}\left(P_{r e f, a}+P_{\mathrm{H}_{2} \mathrm{O}}^{\text {sat }}+P_{\text {ian }}^{\text {backpressure }}\right), \\
& \bar{P}_{\text {icat }}=\frac{1}{2}\left(P_{r e f, c}+P_{\mathrm{H}_{2} \mathrm{O}}^{\text {sat }}+P_{i c a t}^{\text {backpressure }}\right),
\end{aligned}
$$

where: $i=1,2$.

Water saturation pressure $P_{\mathrm{H}_{2} \mathrm{O}}^{\text {sat }}=38.33 \mathrm{kPa}$ was obtained using August-Roche-Magnus equation at dew point temperature of $74.6^{\circ} \mathrm{C}[16]$ :

$$
P_{H_{2} O}^{s a t}=0.61094 \cdot e^{\left(\frac{17.625 \cdot T}{T+243.04}\right)} .
$$

We obtained the following values for anode and cathode pressures: $\bar{P}_{1 a n}=214.16 \mathrm{kPa}, \bar{P}_{1 c a t}=154.16 \mathrm{kPa}$ and $\bar{P}_{2 a n}=184.16 \mathrm{kPa}, \bar{P}_{2 c a t}=134.16 \mathrm{kPa}$. The average partial pressure of the reaction gases $\left(\mathrm{H}_{2}\right.$ and $\left.\mathrm{O}_{2}\right)$ in the PEMFC system can be calculated according to the relations [13]: 


$$
\bar{P}_{i \mathrm{H}_{2}}=\bar{P}_{\text {ian }}-P_{\mathrm{H}_{2} \mathrm{O}}^{\mathrm{sat}} ; \bar{P}_{i \mathrm{O}_{2}}=\left(\bar{P}_{i c a t}-P_{\mathrm{H}_{2} \mathrm{O}}^{\mathrm{sat}}\right) \times 0.21 \text {. }
$$

We obtained the following partial pressures for $\mathrm{H}_{2}$ and $\mathrm{O}_{2}: \bar{P}_{1 \mathrm{H}_{2}}=165.83 \mathrm{kPa}, \bar{P}_{2 \mathrm{H}_{2}}=145.83 \mathrm{kPa}$ and $\bar{P}_{1 O_{2}}=$ $=24.32 \mathrm{kPa}, \bar{P}_{2 \mathrm{O}_{2}}=20.12 \mathrm{kPa}$.

Fig. 3 shows the anodic bipolar graphite plates used in the PEM fuel assembly, with a specific flow pattern based on single channels arranged in the form of a serpentine. The flow fields were created on graphite plates by milling using a Computer Numerical Control (CNC) machine from the research laboratory 3NANO-SAE Research Center Bucharest. DURA-slate ST100 bipolar plates manufactured by Sainergy Tech USA with porosity under 1, graphite volume density of $2 \mathrm{~g} / \mathrm{cm}^{3}$, null gas permeability and electrical conductivity over $300 \mathrm{~S} / \mathrm{cm}$ have been processed here.

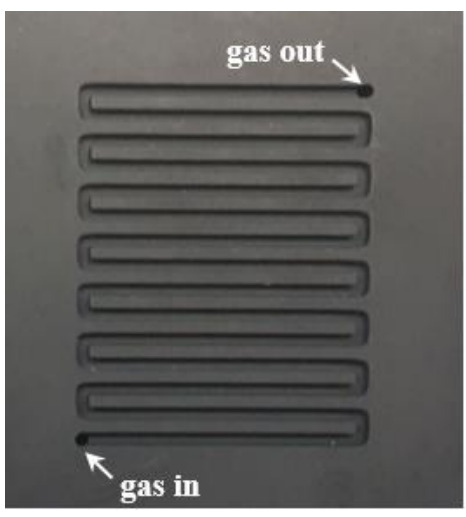

a) $M 1$

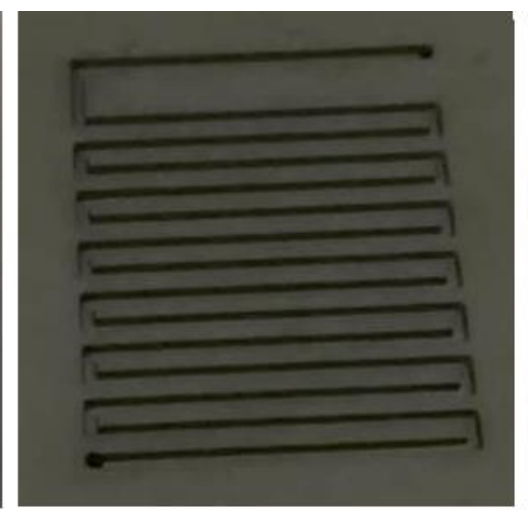

b) $M 2$

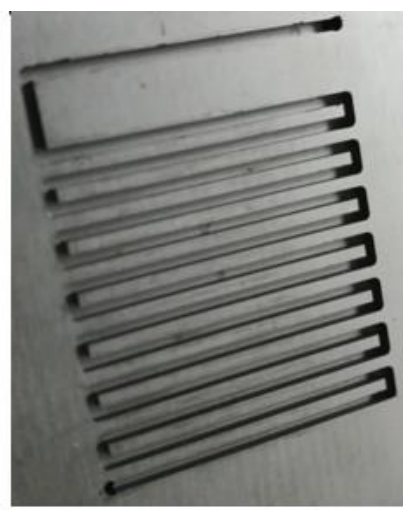

c) $M 3$

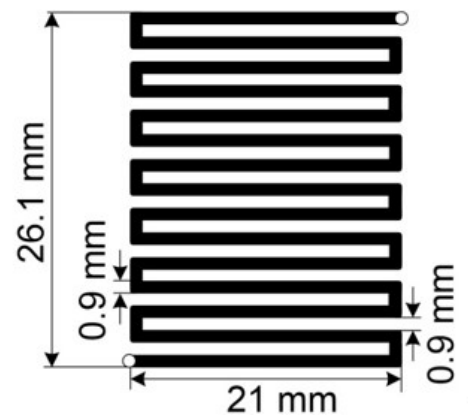

d) $M 1$

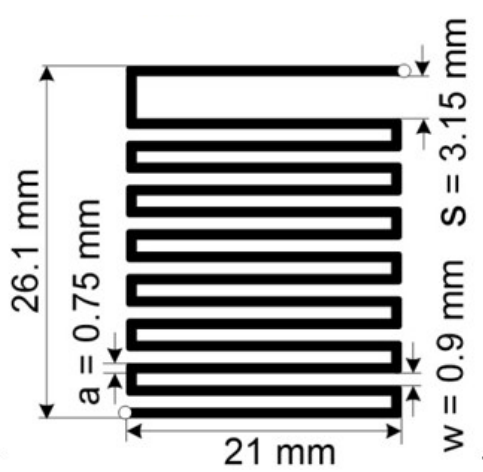

e) $M 2$

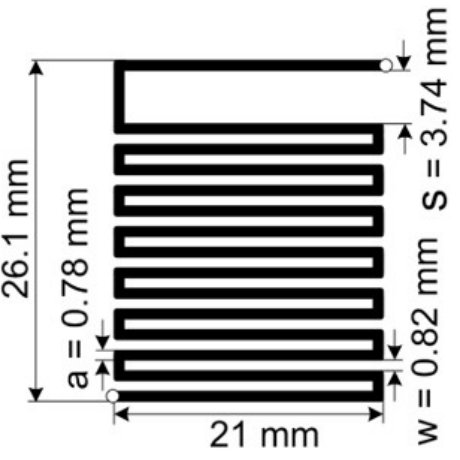

f) $M 3$

Fig. 3 Images of the bipolar graphite plates used at anode $(a-c)$ and geometric dimensions of the serpentine shaped channel fields for the $M 1, M 2$ and $M 3$ models $(\mathrm{d}-\mathrm{f})$

The dimensions of the three experimentally tested flow field models are presented in Table 2.

Table 2

Flow field models implemented on bipolar fields

\begin{tabular}{|c|c|c|c|c|}
\hline Model & $\begin{array}{c}\text { Channels } \\
\text { width } a, \mathrm{~mm}\end{array}$ & $\begin{array}{c}\text { Channels } \\
\text { rib } w, \mathrm{~mm}\end{array}$ & $\begin{array}{c}\text { Distance } s, \\
\mathrm{~mm}\end{array}$ & $\begin{array}{c}\text { Ratio, } \\
w / a\end{array}$ \\
\hline M1 & 0.9 & 0.9 & 0.9 & 1 \\
\hline M2 & 0.75 & 0.9 & 3.15 & 1.2 \\
\hline M3 & 0.78 & 0.82 & 3.74 & 1.05 \\
\hline
\end{tabular}

The purpose of increasing the distance $s$ between the first two flow channels in the gas inlet area was to reduce the pressure drop across the next channels.

Some research studies reported a series of advantages regarding the effect of ratio $w / a>1$ on the PEMFC performance, like an enhanced mechanical support for membrane and Gas Diffusion Layer (GDL), higher water content in the membrane, improved ion conductivity of the membrane, improved heat transfer from membrane to GDL, uniform distribution of the current density and temperature across the membrane and improved performance at high current densities $[17,18]$. A few drawbacks were also distinguished here: a less efficient removal of water as a reaction product through GDL, higher pressure drop across the flow field, a reduced contact area between reactants and GDL and higher overall voltage losses. So, starting from the optimal ratio $w / a=1$ reported from some numerical investigations for serpentine-type flow field in PEMFC [10, 12], we considered here another two ratios $w / a$ higher, but close to 1 (Table 2) in order to establish the flow field with optimal water removal capacity through GDL, reduced pressure along serpentine regions and lowest voltage losses.

\section{Results and discussions}

In accordance with the test protocol adopted here [19], for each set point of the load current, all recorded values of the voltage $U_{i}$ along the 9-minute range considered for each constant current density step (385 values) are converted to a mean $U_{\text {avg }}$. Then the Voltage Standard Deviation $U_{\text {stdev }}$ was calculated for each set of $U_{i}$ values according to the relation [19]: 


$$
U_{\text {stdev }}=\sqrt{\frac{1}{m-1} \sum_{i=0}^{m-1}\left(U_{i}-U_{\text {avg }}\right)^{2}},
$$

where: $m=385$ for the 9-minute time interval considered during experimental testing at all current density steps.

The real value of the experimental voltage was then calculated for each selected current density step, according to the relationship:

$$
U_{\exp _{n}}=U_{\operatorname{avg}_{n}} \pm U_{\text {stdev }_{n}}
$$

where: $n$ represent the number of constant current steps.

In Fig. 4 are presented the experimental polarization curves for models $M 1-M 3$ at two different backpressures.
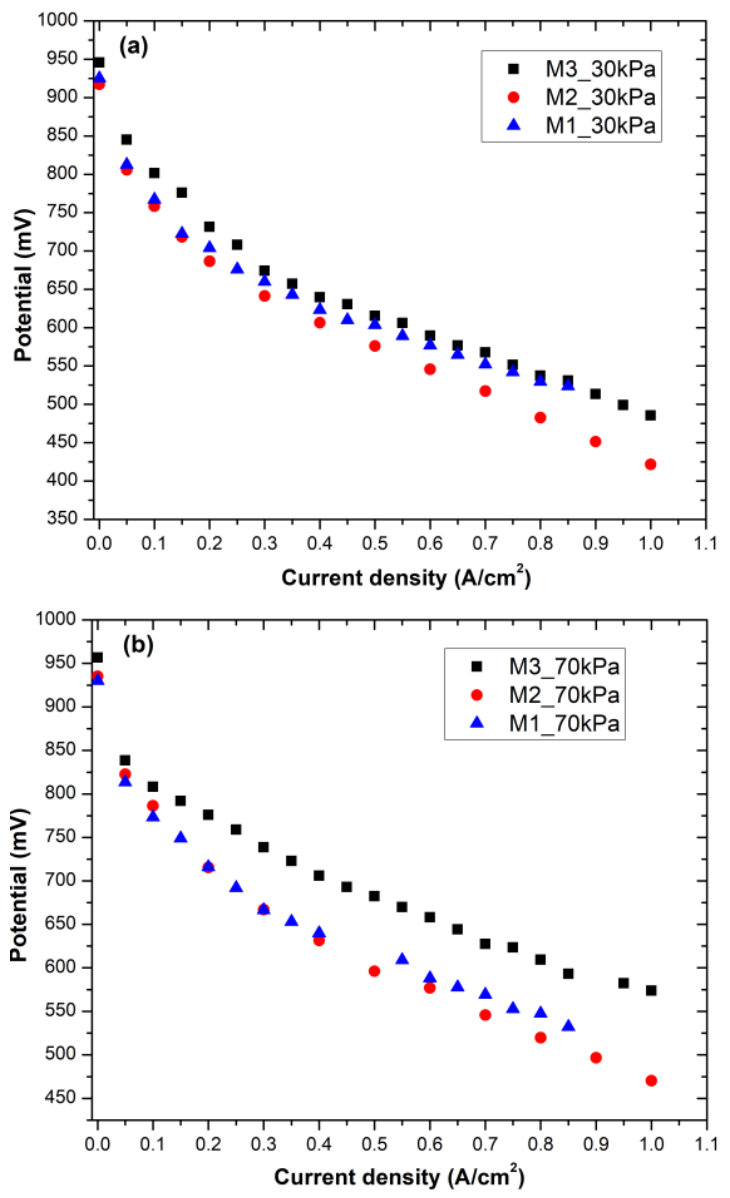

Fig. 4 Experimental polarization curves for the PEMF fuel cell with three different fields for the flow channels, obtained at two backpressures

As we can see in Fig. 4, a, at a backpressure of $30 \mathrm{kPa}$, the fuel cell having the bipolar flow field M2 entered rapidly in the concentration loss region, starting with a current density of only $0.7 \mathrm{~A} / \mathrm{cm}^{2}$. We could observe also here that at current densities over $0.75 \mathrm{~A} / \mathrm{cm}^{2}$, the fuel cell polarization curves for flow fields $M 1$ and $M 3$ are close to each other, due to similar ohmic losses. From Fig. 4, b we noticed almost identical performances of the cell at low current densities (under $0.4 \mathrm{~A} / \mathrm{cm}^{2}$ ) for the flow fields $M 1$ and $M 2$, indicating similar activation losses.

From Fig. 4, b we can notice a reduction in the slope of the polarization curve for the M3 field model compared to the other two models at the backpressure of $70 \mathrm{kPa}$, thus indicating better performance of the bipolar plate with a w/a ratio (land to channel ratio) equal to 1.05. This behavior can be associated with achieving the best compromise between the advantages and disadvantages of using a flow field with $w / a>1$, as mentioned in the literature $[17,18]$.

Also, by comparing the polarization curves of each bipolar plate model tested at two different backpressures (Fig. 4) we could see a decrease in the slope of the curves along the ohmic loss region at backpressures of $70 \mathrm{kPa}$, behavior which indicates an improvement in ion transport across the PEM at the increasing backpressure [18].

The thermodynamic efficiency of the combustion cell $\eta_{F C}$ can be determined as the ratio between the net output power $W_{\text {gross }}$ and the rate of hydrogen usage $m_{H 2}$ in accordance with the following relationship [20]:

$$
\eta_{F C}=\frac{W_{\text {gross }}}{m_{\mathrm{H}_{2}} \cdot L H V_{\mathrm{H}_{2}}},
$$

where: power $W_{\text {gross }}=V_{\text {cell }} \cdot I, \mathrm{~W}$ is calculated for a current level I, A considered. $L H V_{H 2}$ represents the „Lower Heating Value" coefficient, having the value of $120.1 \mathrm{MJ} / \mathrm{kg}$.

The output current is correlated with the $H_{2}$ usage rate in accordance with the relation [21]:

$$
m_{H_{2}}=\frac{I}{2 F} \times M_{H_{2}}, \mathrm{~kg} / \mathrm{s}
$$

where: $M_{H 2}$ represent hydrogen molar mass, having the value of $2.016 \times 10^{-3} \mathrm{~kg} / \mathrm{mol}$ and $F$ is the Faradays constant with the value of $96485.33 \mathrm{~A} \cdot \mathrm{s} / \mathrm{mol}$.

After a correlation of relations (3) and (4) we obtain a simplified expression for thermodynamic efficiency:

$$
\eta_{F C}=\frac{2 V_{c e l l} F}{M_{H_{2}} \cdot L H V_{H_{2}}} .
$$

The variation of the power density for each test performed on PEMFC system is shown in Fig. 5. Fuel cell with flow fields $M 1$ and $M 3$ presented really similar power densities across the entire load current range at the backpressure of $30 \mathrm{kPa}$, as we could observe in Fig. 5, a. At the backpressure of $70 \mathrm{kPa}$, it was noticed an increasing with $10-$ $11 \%$ of the power density at current densities between 0.7 and $0.85 \mathrm{~A} / \mathrm{cm}^{2}$ for the model $M 3$, by comparing with model $M 1$ (Fig. 5, b).

In Fig. 6 was plotted the thermodynamic efficiency determined on the basis of the relationship (9) for the two experimental tests of the PEMFC system, with different types of bipolar plate flow fields.

In the case of model $M 2$ with the highest $w / a$ ratio of 1.2 was observed a rapid exponential decrease of the thermodynamic efficiency starting from a power density of $0.25 \mathrm{~W} / \mathrm{cm}^{2}$, from 0.48 to 0.33 at a backpressure of $30 \mathrm{kPa}$ (Fig. 6, a). Model M3 presented a linear variation of thermodynamic efficiency along the entire power density domain at backpressure of $70 \mathrm{kPa}$, with values increased by 7 $-14 \%$ at power densities between $0.115-0.44 \mathrm{~W} / \mathrm{cm}^{2}$ by comparing with model $M 2$, as we could notice in Fig. 6, b. 

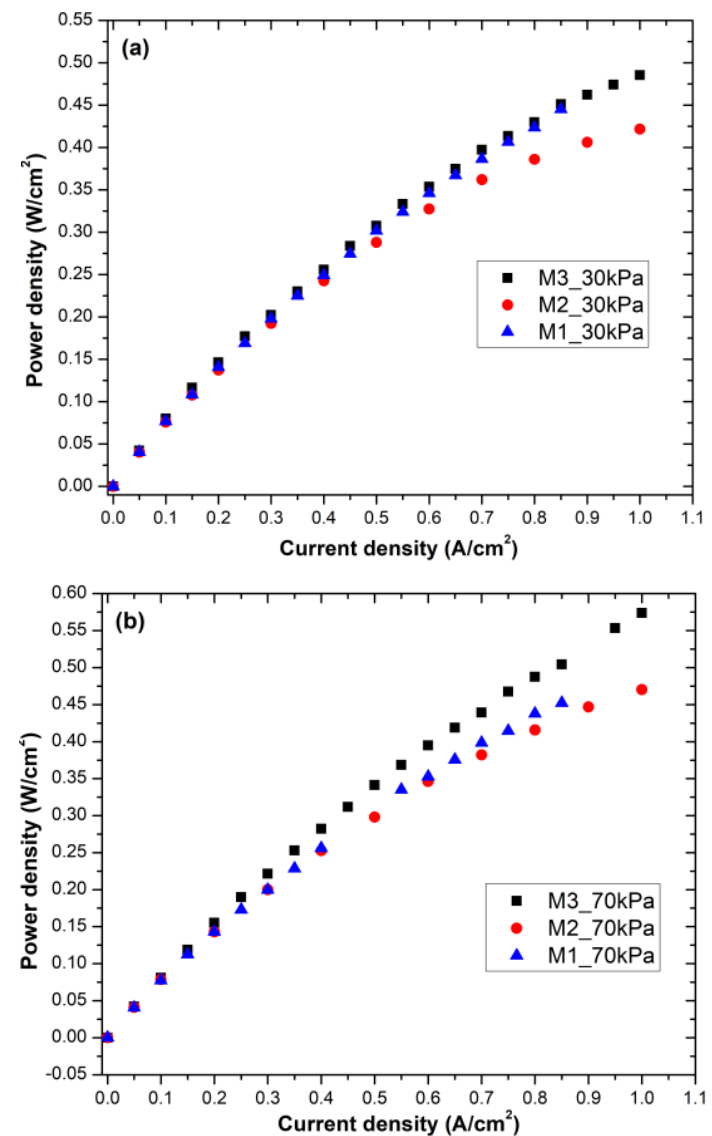

Fig. 5 Variation of the power density for the PEM fuel cell with bipolar flow fields M1 - M3, working at two different backpressures
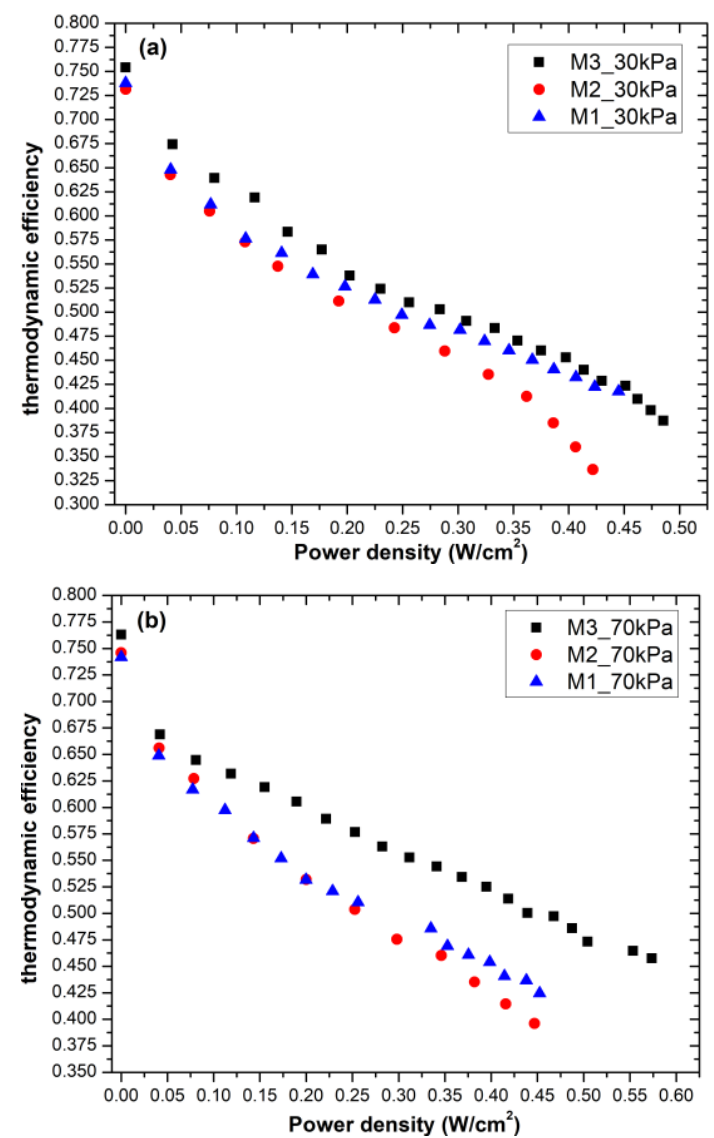

Fig. 6 Experimental variation of thermodynamic efficiency at various values of power density for the PEMFC system

\section{Conclusions}

At a system backpressure of $30 \mathrm{kPa}$, with partial pressures of $145.8 \mathrm{kPa}$ for $\mathrm{H}_{2}$ and $20.1 \mathrm{kPa}$ for $\mathrm{O}_{2}$ inside the PEM fuel cell, the flow field M3 with ratio w/a $=1.05$ presented the polarization curve with lowest activation and ohmic losses till at a current density of $0.75 \mathrm{~A} / \mathrm{cm}^{2}$. After this value, at high current densities, the ohmic losses for the models $M 3$ and $M 1$ (with w/a ratio of 1) seemed to be similar.

At a backpressure of $70 \mathrm{kPa}$, with partial pressures of $165.8 \mathrm{kPa}$ for $\mathrm{H}_{2}$ and $24.3 \mathrm{kPa}$ for $\mathrm{O}_{2}$ through the cell, a big slope reduction for polarization curve of the model $M 3$ was observed, suggesting a much better electrical performance of the fuel cell with this type of the gas flow field along the entire current density domain.

The power density curves for the cell with flow fields M1 and M3 proved to be near to each other at a backpressure of $30 \mathrm{kPa}$, but at a higher backpressure a clear enhancement of $10-11 \%$ was observed for model M1 at current densities over $0.7 \mathrm{~A} / \mathrm{cm}^{2}$.

Optimized model M3 presented the highest thermodynamic efficiency along the entire power density domain for both pressure conditions considered in the experimental testing.

\section{References}

1. Fathabadi, H. 2018. Novel fuel cell/ battery/ supercapacitor hybrid power source for fuel cell hybrid electric vehicles, Energy 143: 467 - 477. https://doi.org/10.1016/j.energy.2017.10.107.

2. Das, H.S.; Tan C.W.; Yatim A.H.M. 2017. Fuel cell hybrid electric vehicles: A review on power conditioning units and topologies, Renewable and Sustainable Energy Reviews 76: 268-291. https://doi.org/10.1016/j.rser.2017.03.056.

3. Rajashekara, K.; Rathore, A.K. 2015. Power conversion and control for fuel cell systems in transportation and stationary power generation, Electr. Power Compon. Syst. 43: 1376-1387. https://doi.org/10.1080/15325008.2015.1034383.

4. Wu, B.; Martian, M.; Offer, G.J. 2012. Hydrogen PEMFC system for automotive applications, Int. J. LowCarbon Tech. 7(1): 28-37. https://doi.org/10.1093/ijlct/ctr026.

5. Lobato, J.; Cañizares, P.; Rodrigo, M.A.; Pinar, F.J.; Úbeda, D. 2011. Study of flow channel geometry using current distribution measurement in a high temperature polymer electrolyte membrane fuel cell, J. Power Source 196: 4209-4217. https://doi.org/10.1016/j.jpowsour.2010.10.017.

6. Liu, H.; Li, P.; Juarez-Robles D., K. Wang and A. Hernandez-Guerrero. 2014. Experimental study and comparison of various designs of gas flow fields to PEM fuel cells and cell stack performance, Frontiers in Energy Research 2: 1- 8 . https://doi.org/10.3389/fenrg.2014.00002.

7. Li, X.; Sabir, I.; Park, J. 2007. A flow channel design procedure for PEM fuel cells with effective water removal, J. Power Sources 163: 933-942. https://doi.org/10.1016/j.jpowsour.2006.10.015.

8. Park, J.; Li, X. 2007. An experimental and numerical investigation on the cross flow through gas diffusion 
layer in a PEM fuel cell with a serpentine flow channel, J. Power Sources 163: 853-863.

https://doi.org/10.1016/j.jpowsour.2006.09.083.

9. Jithesh, P.K.; Bansode, A.S.; Sundararajan, T.; Sarit, K.D. 2012. The effect of flow distributors on the liquid water distribution and performance of a PEM fuel cell, Int. J. Hydrogen Energy 37: 17158-17171. https://doi.org/10.1016/j.ijhydene.2012.08.058.

10. sieh S.S.; Chu K.M. 2007. Channel and rib geometric scale effects of flow field plates on the performance and transient thermal behavior of a micro-PEM fuel cell, J Power Sources 173: 222-232. https://doi.org/10.1016/j.jpowsour.2007.08.005.

11. Kerkoub, Y.A.; Benzaoui, A.; Haddad, F.; Ziari, Y.K. 2018. Channel to rib width ratio influence with various flow field designs on performance of PEM fuel cell, Energy Conversion and Management 174: 260-275. https://doi.org/10.1016/j.enconman.2018.08.041.

12. Lakshminarayanan, V.; Karthikeyan, P. 2016. Optimization of Flow Channel Design and Operating Parameters on Proton Exchange Membrane Fuel Cell Using MATLAB, Period. Polytech. Chem. Eng. 60: 173-180. https://doi.org/10.3311/PPch.8461.

13. Zhang, J.; Li, H.; Zhang, J. 2009. Effect of Operating Backpressure on PEM Fuel Cell Performance, ECS Transactions 19(31): 65-76. https://doi: 10.1149/1.3271363.

14. Zhang, J.L.; Song, C.; Zhang, J.; Baker, R.; Zhang L. 2013. Understanding the effects of backpressure on PEM fuel cell reactions and performance, Journal of Electroanalytical Chemistry 688: $130-136$. https://doi.org/10.1016/j.jelechem.2012.09.033.

15. Dehsara, M.; Kermani, M.J. 2013. The effects of operating parameters on the performance of proton exchange membrane fuel cells, Mechanika 19(6): 649-656. http://dx.doi.org/10.5755/j01.mech.19.6.5989.

16. Alduchov, O.A.; Eskridge, R.E. 1996. Improved Magnus form approximation of saturation vapor pressure, $\mathbf{J}$. Applied Metrology 35: 601-608. https://doi.org/10.1175/1520- 450(1996).

17. Shimpalee, S.; Van Zee, J.W. 2007. Numerical studies on rib \& channel dimension of flow-field on PEMFC performance, Int. J. Hydrogen Energy 32(7): 842-856. https://doi.org/10.1016/j.ijhydene.2006.11.032.
18. Kahraman, H.; Orhan, M.F. 2017. Flow field bipolar plates in a proton exchange membrane fuel cell: Analysis \& modeling, Energy Conversion and Management 133: 363-384.

19. Tsotridis, G.; Pilenga, A.; De Marco, G.; Malkow, T. 2015. EU Harmonized test protocols for PEMFC MEA testing in single cell configuration for automotive applications, JRC Science for Policy report, EUR 27632 EN; https://doi: 10.2790/54653.

20. Cownden, R.; Nahon, M.; Rosen, M.A. 2001. Modelling and analysis of a solid polymer fuel cell system for transportation applications, International Journal of Hydrogen Energy 26: 615-623. https://doi.org/10.1016/S0360-3199(00)00126-9.

21. Basualdo, M.S.; Feroldi, D.; Outbib, R. 2012. PEM Fuel Cells with Bio-Ethanol Processor Systems, 49 Green Energy and Technology, Springer-Verlag London Limited. $461 \mathrm{p}$.

https://doi 10.1007/978-1-84996-184-4.

A. Andronie, I. Stamatin, V. Girleanu, V. Ionescu,

N. Buzbuchi

\section{EXPERIMENTAL STUDY OF A PEMFC SYSTEM WITH DIFFERENT DIMENSIONS OF THE SERPENTINE TYPE CHANNELS FROM BIPOLAR PLATE FLOW FIELDS}

S u m m a r y

In this study, a BEKKTECH BT-552 PEMFC test station was used in order to investigate the effect of a three different gas flow fields (with $w / a$ ratios of $1,1.05$ and 1.2) on fuel cell performance at two different system backpressures of $70 \mathrm{kPa}$ (Test no. 1) and $30 \mathrm{kPa}$ (Test no. 2), respectively. The nominal efficiency of the PEM fuel cell was an arbitrary value, located in the domain $0.76-0.46$ for Test no. 1 and $0.75-0.39$ for Test no. 2 in the case of the optimized flow field model M3, with w/a ratio of 1.05 .

Keywords: channel width, power density, efficiency.

Received October 30, 2018 Accepted February 15, 2019 